\title{
Geochemical variations due to salinization in groundwater along the southeast coast of India
}

\author{
Thilagavathi Rajendiran ${ }^{1}$. Chidambaram Sabarathinam ${ }^{1,2}$. Thivya Chandrasekar ${ }^{3}$. Banajarani Panda ${ }^{1}$. \\ Mahalakshmi Mathivanan ${ }^{4}$. Ganesh Nagappan ${ }^{1}$. Devaraj Natesan ${ }^{1}$. Meenu Ghai ${ }^{5}$. Dhiraj Kumar Singh ${ }^{6}$. \\ Ramanathan Alagappan ${ }^{7}$
}

Received: 1 October 2020 / Accepted: 1 April 2021

Published online: 26 April 2021

(c) The Author(s) 2021

OPEN

\begin{abstract}
In recent years, the extraction of groundwater (GW) in coastal aquifers has rendered the fragile aquifers more saline due to the sea water intrusion. Groundwater from the coastal aquifers of the Pudhucherry region were sampled to study the process of salinization. An integrated approach was adopted to identify the salinization process, by coordinating the results of borehole geophysics, rainfall pattern, water level variation, hydrochemical characters and multivariate statistical analysis. A total of 136 groundwater samples were collected during two different seasons, southwest monsoon (SWM) and northeast monsoon (NEM). The major cations and anions were analyzed adopting standard procedures. Resistivity and litholog indicate that the southeastern (SE) part of the study region has lower resistivity than in north. Based on electrical conductivity (EC) and total dissolved solids (TDS) values, most of the samples are potable, except for few samples from southeastern region. The study results indicated that higher values of $\mathrm{Na}, \mathrm{EC}, \mathrm{K}, \mathrm{SO}_{4}, \mathrm{Mg}$ and $\mathrm{Cl}$ were observed during NEM, indicating leaching of salt into the aquifer and ion exchange process. The predominant hydrochemical facies of groundwater was $\mathrm{Na}-\mathrm{Cl}$ and $\mathrm{Ca}-\mathrm{Mg}-\mathrm{Cl}$ type reflecting the saline water and the mixing process of saltwater and fresh groundwater, respectively. Though more number of samples with higher EC was noted in NEM, the results of PCA and correlation analysis indicate the predominance of leaching of salts and intense agricultural activities. The process of sea water intrusion was observed to be dominant during SWM.
\end{abstract}

Keywords Groundwater · Saline water intrusion · Fresh water · Factor score

\section{Introduction}

Aquifers along the coastal area are important sources of water, and it is usually affected by the diverse landuse practices and geochemical contaminants. Eight percentage of global population live along the coastal region and utilize the local aquifers for their needs [1-5]. The groundwater extraction from the coastal aquifers [6-8], leads to reduction in available fresh water (FW) and thus causes the lowering of water table resulting in the decrease in groundwater quality.

Various factors such as seawater intrusion, rock-water interaction, excess usage of groundwater, sea level rise, temperature variance, hydrogeological history of the area,

Chidambaram Sabarathinam, chidambaram_s@rediffmail.com; $₫$ Mahalakshmi Mathivanan, mahalakshmi@civil.sastra.edu| ${ }^{1}$ Department of Earth Sciences, Annamalai University, Annamalai Nagar, Chidambaram, Tamil Nadu, India. ${ }^{2}$ Water Research Center, Kuwait Institute for Scientific Research, Kuwait City, Kuwait. ${ }^{3}$ Department of Geology, Madras University, Chennai, India. ${ }^{4}$ School of Civil Engineering, Sastra Deemed University, Tamil Nadu, Thanjavur, India. ${ }^{5}$ Department of Chemistry, Kishan Lal Public College Rewari, Haryana, India. ${ }^{6}$ Grass Roots Research and Creation India (P) Ltd, Noida, India. ${ }^{7}$ School of Environmental Sciences, JNU, New Delhi, India. 
salt panning, inadequate removal of manure and use of biochemical foods govern the salinization of groundwater [9-11]. Globally, a complex interplay of the abovementioned facts along with seawater intrusion into these coastal aquifers leads to geochemical hazard in groundwater along the coastal aquifers.

The amount of groundwater extracted from the coastal aquifers, hydrogeological conditions, the well design, fresh water sources (ponds, rivers or reservoirs) play a major role in the management of the sustainable utilization. Subsequently, the landuse pattern along the shore line determined the quantum of groundwater extracted from the aquifers which results in seawater intrusion, and in fact, this is also facilitated by sea level rise. [4]. The reduction of fresh water flow to the sea has increased the inland surface backwater flow enhancing the infiltration of brackish water into the adjacent flood plains. One of the most important techniques to determine the saline water intrusion is to enhance the monitoring of the groundwater geochemistry [12-18]. Groundwater with higher TDS are generally more saline in nature [19], and saline groundwater along the coast also have reported higher amount of trace metals apart from major cation and anions $[14,20]$.

The seawater intrusion (SWI) in the coastal region not only renders the quality of groundwater non-potable but also affects the vegetation, soil conditions and the sustainability of groundwater [21]. The mixing of seawater and freshwater in coastal aquifers leads to the lateral migration of sea water into the aquifer affecting the groundwater chemistry. The chief geochemical process observed in the coastal sedimentary aquifers with clay is ion exchange [22]. The mixing of seawater-freshwater and the ion exchange process are inferred from the ion ratios [23-25]. Further, the geochemical nature of the groundwater and the status of the sea water intrusion have been studied in the sedimentary coastal aquifers by using hydrochemical facies evolution diagram $[22,24,26,27]$. In numerous coastal aquifers [11,28-32], the hydrochemical facies evolution diagram had proved to be promising in identifying the spatiotemporal variation in seawater intrusion [33-35]. The lithology also plays a vital role in seawater intrusion as the flow of water in the aquifer is governed by the aquifer properties such as porosity and permeability [36].

The spatial variation of major ions in groundwater of the coastal aquifers and the changes in the geochemical processes can be established by integration the geochemical parameters in the GIS platform [37]. Apart from GIS techniques, other softwares like WATCLAST and CHIDAM are also used to plot, assess and categorize the groundwater $[38,39]$ and to identify the process of mineral weathering, evaporation and its suitability. Modeling softwares like PHREEQC determine the saturation states of minerals and predict their variation with an increase in evaporation and salinity [40]. AquaChem software determines that groundwater type and facilitates the plotting of standard diagrams like Wilcox plot and Piper facies. The statistical softwares plays a key role in determining the hidden process and identify the relationship between ions, thereby the source and process governing the geochemistry of groundwater [41].

Groundwater is unsuitable for irrigation in the coastal area due to the higher concentration of sodium ion. The earlier researchers had identified that this high concentration in the coastal groundwater is attributed to insufficient flushing into the sea and the fine-grained composition of aquifer sediments [42]. Enhancement of rainfall recharge and sustenance of the fresh surface water bodies like rivers, lakes and reservoirs control the salinity and help to derive a proper management strategy over a long period of time. The coastal saline groundwater is reported to have greater concentration of major ions and bromide [43]. The groundwater of arid coastal regions are hypersaline [44], and their spatial distributions show high nitrate, chloride, $\mathrm{H}_{2} \mathrm{~S}$ and ammonium [45].

The current study area is located at Pondicherry, southeast coastal India, and it is densely populated with more industrial, urban and rural population. Groundwaterdependent agriculture is one of the major landuse patterns and is one of the most prominent tourist centers in southeast India, with greater density of population. The domestic and the agricultural needs of the coastal regions are mainly supported by the groundwater resources in this region. Hence, the groundwater reserve become a prime water resource and is consequently exploited. In this scenario, the groundwater-seawater interface varies frequently and the salinity is observed to increase toward inland in the recent years. Studies have tried to demarcate the seawater intrusion through modeling techniques [46, 47]. Hydrogeochemical parameters to determine the seawater intrusion [46], and delineation of the areal extent of seawater intrusion by preparing a vulnerability map by [47] were also attempted by the earlier researchers. The studies on geochemical processes for limited area and limited samples were attempted $[48,49]$ and inferred that the geochemical weathering and ion exchange are the predominant factors. Apart from these studies, geophysical studies using borehole data, to determine the lithological variations [48]; studies on the geomorphology of the region [50]; saturation index of groundwater [51]; assessment of rainfall recharge using stable isotopes [52]; microbial contamination [53]; budgeting of groundwater with respect to water level variations [54] and dissolved organic carbon in groundwater [55-60] were also attempted by earlier researchers. The current study integrates the geophysical techniques such as resistivity and lithology, the temporal change of water level and rainfall along with the 
hydrogeochemical investigation of groundwater samples to assess the salinity in this coastal aquifer. Thus, the study aims to assess the salinization in the coastal groundwater of the regions using integrated techniques.

\section{Study area}

The present study area is located in the southern part of Tamil Nadu, within latitudes of $11^{\circ} 45^{\prime}$ and $12^{\circ} 03^{\prime}$ and longitude of $79^{\circ} 37^{\prime}$ and $79^{\circ} 53^{\prime}$, representing the survey of India, toposheet maps of No.58 M/9, M/13 and $57 \mathrm{P} / 12$ and $\mathrm{P} / 16$, with a geographical extent of $293 \mathrm{~km}^{2}$, divided into

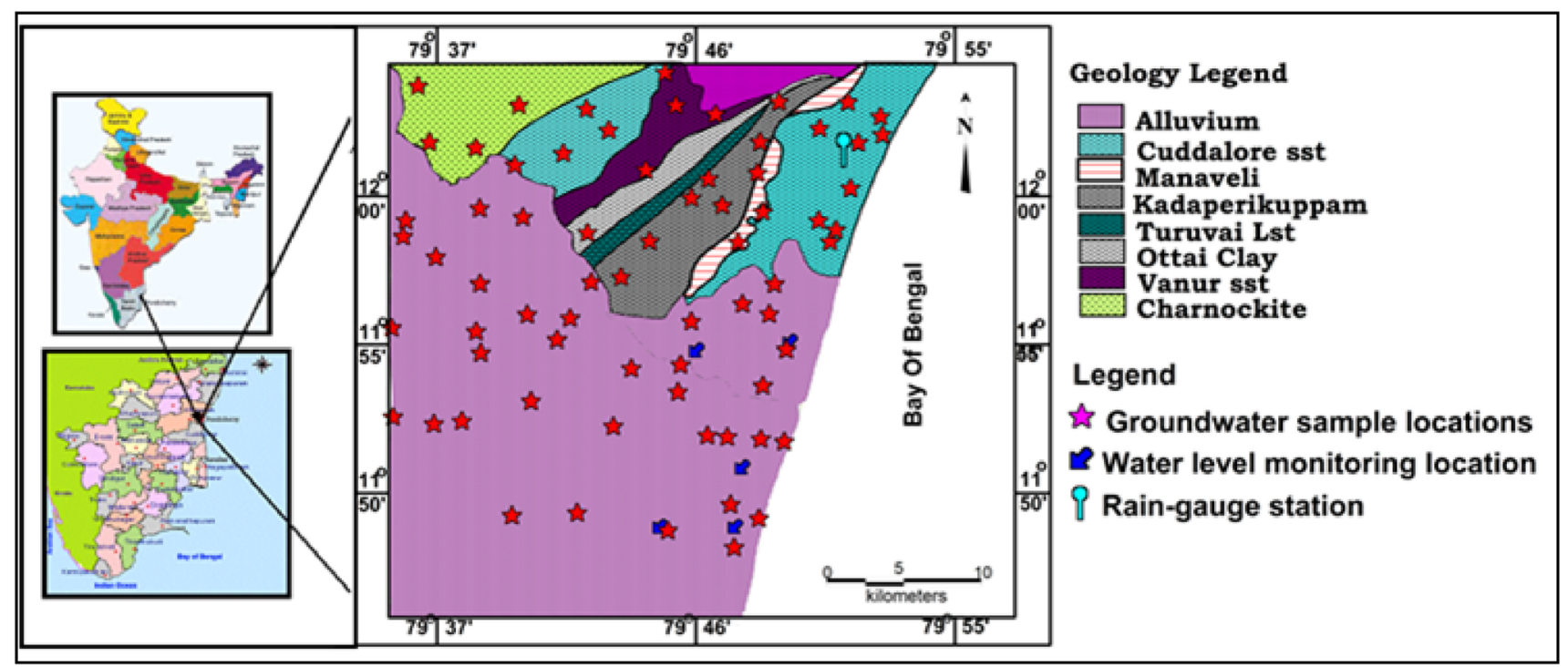

Fig. 1 The geology map of the study area showing the location of the samples collected

Table 1 Stratigraphic succession for the study region [88]

\begin{tabular}{|c|c|c|c|}
\hline Era & Period & Formation & Typical lithology \\
\hline \multirow[t]{2}{*}{ Quaternary } & Recent & Alluvium Laterite & Sands, clays, silts, Kankar, Laterite gravels \\
\hline & & Upper Cuddalore Formation & $\begin{array}{l}\text { Sandstones with minor clays and siltstones with thin seams of lignite are } \\
\text { pebbly and gravelly and coarse grained }\end{array}$ \\
\hline Tertiary & Mio-Pliocene & Lower Cuddalore Formation & $\begin{array}{l}\text { Dirty white, light gray sandstone, marcasite siltstones rich with thin clay } \\
\text { lignite seams }\end{array}$ \\
\hline \multicolumn{4}{|c|}{ Unconformity } \\
\hline \multirow[t]{2}{*}{ Tertiary } & & Manaveli Formation & $\begin{array}{l}\text { Yellow and yellowish brown, calcareous gray siltstone and claystone and } \\
\text { shale with limestone bands }\end{array}$ \\
\hline & Paleocene & Kadaperikuppam formation & $\begin{array}{l}\text { White to dirty white yellowish sandy rough fossiliferous calcareous; calcare- } \\
\text { ous sandstone and clay }\end{array}$ \\
\hline \multicolumn{4}{|c|}{ Unconformity } \\
\hline \multirow[t]{4}{*}{ Mesozoic } & Upper Cretaceous & Turuvai limestone & $\begin{array}{l}\text { Extremely limestone fossiliferous, conglomerate in areas, calcareous Sand- } \\
\text { stone and clays }\end{array}$ \\
\hline & & Ottai claystone & $\begin{array}{l}\text { Claystones, silts with thin bands of sandy limestone and fine-grained calcar- } \\
\text { eous sandstone, grayish to grayish green }\end{array}$ \\
\hline & & Vanur sandstone & $\begin{array}{l}\text { Hard coarse grained quartzite sandstone, rarely feldspathic or calcareous } \\
\text { with small clays }\end{array}$ \\
\hline & Lower Cretaceous & $\begin{array}{l}\text { Ramanathapuram forma- } \\
\text { tion (unexposed) }\end{array}$ & $\begin{array}{l}\text { Silty black carbonaceous clay and fine to medium grained sands with lignite } \\
\text { bands and medium to coarse grained sandstones }\end{array}$ \\
\hline \multicolumn{4}{|c|}{ Unconformity } \\
\hline Archaean & & Eastern Ghats Complex & Charnockite and hornblende gneiss biotite \\
\hline
\end{tabular}


7 municipalities (Fig. 1) and 179 villages. The River Gingee and Pennaiyar's deltaic channel are the major source of drainage of the study area. The area encompasses sedimentary deposits, with geological age from Cretaceous to Quaternary (Table1). The sedimentary formation of Cretaceous covers in the northwestern, northern part of Gingee River in the study area. However, the Tertiary comprises the Paleocene of Kadaperikuppam and Manaveli Formations and Mio-Pliocene Cuddalore Formation. The recent formation is characterized by Quaternary laterites and alluvium. Usually, the study area is a peneplain with a mean altitude of around $15 \mathrm{~m}$ above mean sea level (amsl). Geomorphologically, the area is covered with three features such as alluvial plain, uplands and coastal plain.

The hot and humid climate persists in the study area with a temperature fluctuation between 22 and 33 degrees Celsius. The area receives an average annual precipitation of $1281 \mathrm{~mm}$. Northeast monsoon contributes to a major part of rainfall received in the study area (63\%); likewise, southwest monsoon contributes to $29 \%$ of total rainfall [61]. The depth to water level ranges from 1.5 to $27 \mathrm{~m}$ below groundwater level (mbgl). The transmissivity range for the oldest Cretaceous aquifers is from 92 to 1925 $\mathrm{m}^{2} /$ day, and the storage coefficient is between $2.94 \times 10^{-5}$ and $1.37 \times 10^{-4}[62,63]$. Similarly, for the Tertiary aquifers transmissivity was assessed as $2000 \mathrm{~m}^{2} /$ day and the storage coefficient ranges between $9.58 \times 10^{-5}$ to $8.99 \times 10^{-4}$. For the recent alluvium aquifers, the transmissivity ranges between $275.4 \mathrm{~m}^{2} /$ day and $770 \mathrm{~m}^{2} /$ per day.

\section{Materials and methods}

The rainfall data and depth of water level were collected from CGWB [61]. Resistivity and litholog used for the study were collected from borewell companies [49]. A total number of 68 groundwater samples were collected from the study area (Fig. 1) during NEM (November) of 2016 and SWM (July) of 2017 to compare the seasonal variation in groundwater chemistry of the region. The samples were collected from the production wells after purging the well for $15 \mathrm{~min}$.

The collected samples were filtrated with 0.45 micron fiber membrane filters and measured for physical parameters like $\mathrm{pH}, \mathrm{EC}$ and TDS by using a Thermo Orion ion electrode. The samples were acidified by adding few drops of $\mathrm{HNO}_{3}$ acid for the cation analysis. Subsequently, the collected samples were brought to the laboratory and refrigerated in a temperature of 4 degrees Celsius until analysis. The samples were analyzed for the major cations like $\mathrm{Ca}, \mathrm{Mg}, \mathrm{Na}, \mathrm{K}$ and anions like $\mathrm{Cl}, \mathrm{HCO}_{3}, \mathrm{NO}_{3}$, $\mathrm{SO}_{4}$ and $\mathrm{PO}_{4}$. The cations like $\mathrm{Ca}$ and $\mathrm{Mg}$ were determined by titration method, and $\mathrm{K}$ and $\mathrm{Na}^{+}$were analyzed using a flame photometer. Similarly, the anions $\left(\mathrm{PO}_{4}, \mathrm{NO}_{3}\right.$ and $\left.\mathrm{SO}_{4}\right)$ were analyzed using the spectrophotometer. The titration method was adopted to measure bicarbonate $\left(\mathrm{HCO}_{3}\right)$ and $\mathrm{Cl}$. The detail analytical instrumentation and its detection limits are provided in Table 2 . The standard procedure of American Public Health Association was followed for the analysis of major ions [64]. The spatial distribution maps were prepared in GIS interface by using MAP Info software.

\section{Results and discussion}

\subsection{Resistivity and lithology elucidation}

The subsurface distribution of resistivity and lithology of eight different locations, namely Ariyankuppam, Chinverampattinam, Keezh Parikalpattu, Muthalyarpet, Nallavadu, Pillaiyarkuppam, Reddiyarpallayam, Thavalakuppam, are plotted as given in Fig. 2 by using the software Rockworks (version 14). The deeper aquifer has lowest resistivity in the northern part; however, the resistivity value has an
Table 2 Analytical instruments and its detection limits for the groundwater samples

\begin{tabular}{lll}
\hline Parameters & Instruments and its model & Detection limit \\
\hline $\mathrm{pH}$ & Ion electrode/Thermo Orion five-star meter & $0-20$ \\
$\mathrm{EC}$ & & $0-3000 \mathrm{mS}$ \\
$\mathrm{TDS}$ & Volumetric methods/titration using burette, flasks & $0-20,000 \mathrm{ppm}$ \\
$\mathrm{Ca}$ & & $\pm 0.05 \mathrm{~mL}$ \\
$\mathrm{Mg}$ & & \\
$\mathrm{Cl}$ & & \\
$\mathrm{HCO}_{3}$ & Spectrophotometer/HACH (DR 6000) & \\
$\mathrm{SO}_{4}$ & & $0-70 \mathrm{mg} / \mathrm{L}$ \\
$\mathrm{PO}_{4}$ & & $0-25 \mathrm{mg} / \mathrm{L}$ \\
$\mathrm{NO}_{3}$ & $0-10 \mathrm{mg} / \mathrm{L}$ \\
$\mathrm{H}_{4} \mathrm{SiO}_{4}$ & & $0-10 \mathrm{mg} / \mathrm{L}$ \\
$\mathrm{Na}$ and K & Flame photometer/Elico CL 378 & $1-100 \mathrm{ppm}$ \\
\hline
\end{tabular}



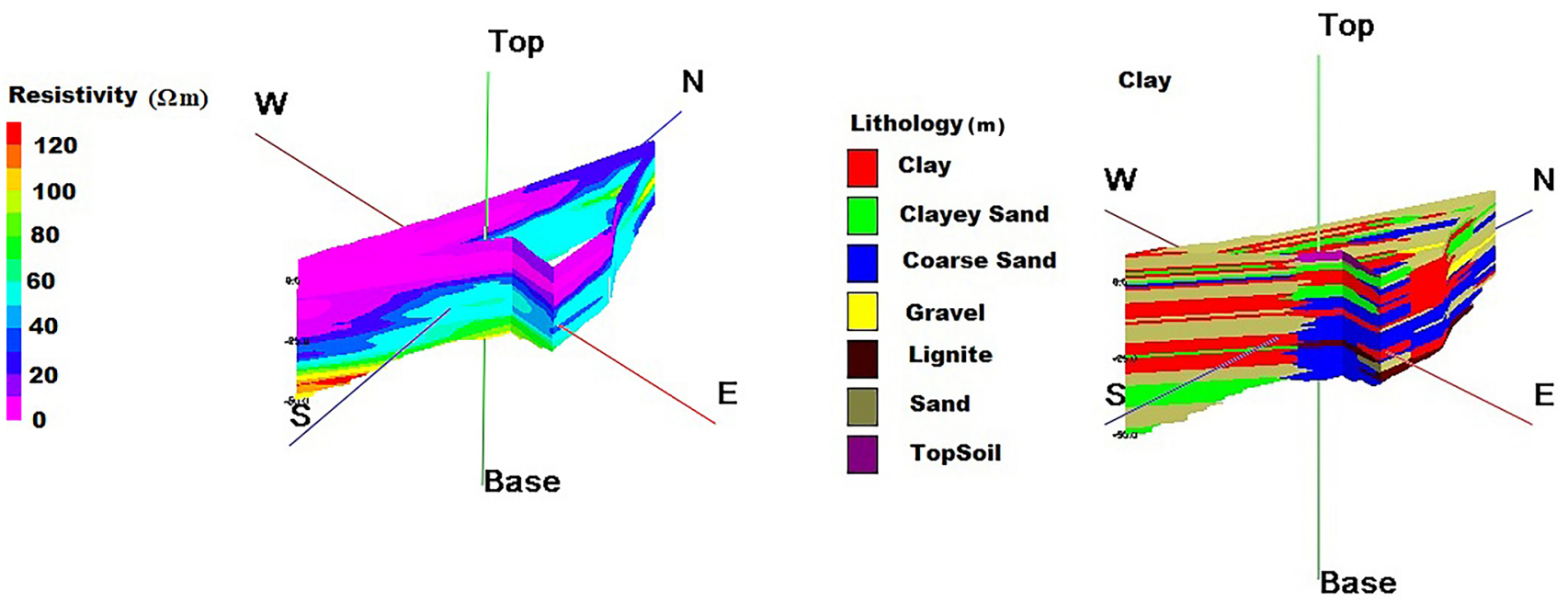

Fig. 2 3D variation of Resistivity $(\Omega \mathrm{m})$ and lithology $(\mathrm{m})$ of the Study region

increasing trend toward southwestern part of the area. Subsequently, the subsurface distribution of lithological units shows that there is a disseminated patch of clay and lignite layer (Fig. 2). The presence of thick clay layers in the shallow depth along southwestern region lowers resistivity; however, the presence of clayey sand and sand influence the resistivity in depth. Low resistivity values in sand and clayey sand layer at greater depth near southwestern part indicate influence of saline intrusion. However, the presence of sand and coarse sand in the northern and northeastern part of the study area has relatively higher resistivity values indicating the present of fresh water.

\subsection{Rainfall and water level}

Groundwater level information for five bore wells Mangalam, Kattukuppam, Pondicherry, Viliyanur and Reddichavadi for the period of 2016-17 was considered to understand the status of water level fluctuation in this area. The shallowest water level as $1.4 \mathrm{mbgl}$ is recorded at Kattukuppam during 2016, and the deepest water level of $19.0 \mathrm{mbgl}$ was observed at Mangalam in 2016. While comparing the depth of five monitoring wells, the average water level data of both the year 2016 and 2017 (Fig. 3) are recorded as 19 and $17 \mathrm{mbgl}$. The shallowest water level during 2016 might be referring to the surplus rainfall occurred during the NEM of 2016 (Fig. 4). In the year 2017, the water level was relatively deeper in almost all the stations due to inadequate rainfall (Fig. 4). Thus, rainfall variation is considered as the major cause of water level fluctuation in the area apart from the groundwater exploitation.

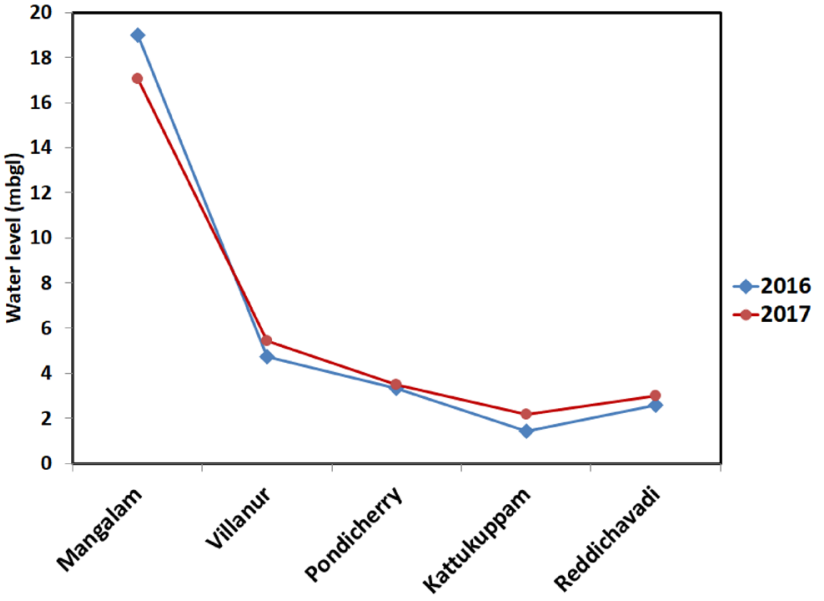

Fig. 3 Total average annual water level (mbgl) from the period of 2016 and 2017

\subsection{Physico-chemical parameters}

The EC values range between $469-3830 \mu \mathrm{S} / \mathrm{cm}$ in NEM and $751-2343 \mu \mathrm{S} / \mathrm{cm}$ in SWM. Maximum concentration of EC during NEM is observed in the Thavalakuppam reflecting the mixing of saline water, $51 \%$ of samples were identified with higher EC exceeding the desirable limit of $1400 \mu \mathrm{S} /$ $\mathrm{cm}$, and during SWM, higher EC is noted at Thengaithittu location. According to classification by Saxena [14], most of the samples are within brackish to saline nature.

The $\mathrm{pH}$ ranges between 6.7 and 7.9 in NEM, highly alkaline water is noted in Nesal sample location, and acidic samples are noted in Gangamadevi location. During SWM, the $\mathrm{pH}$ ranges between 5.2 and 9.5. However, the temperature ranges between $26-32^{\circ} \mathrm{C}$ and $29-34^{\circ} \mathrm{C}$ for NEM and SWM, respectively. The TDS varies between 310 and 


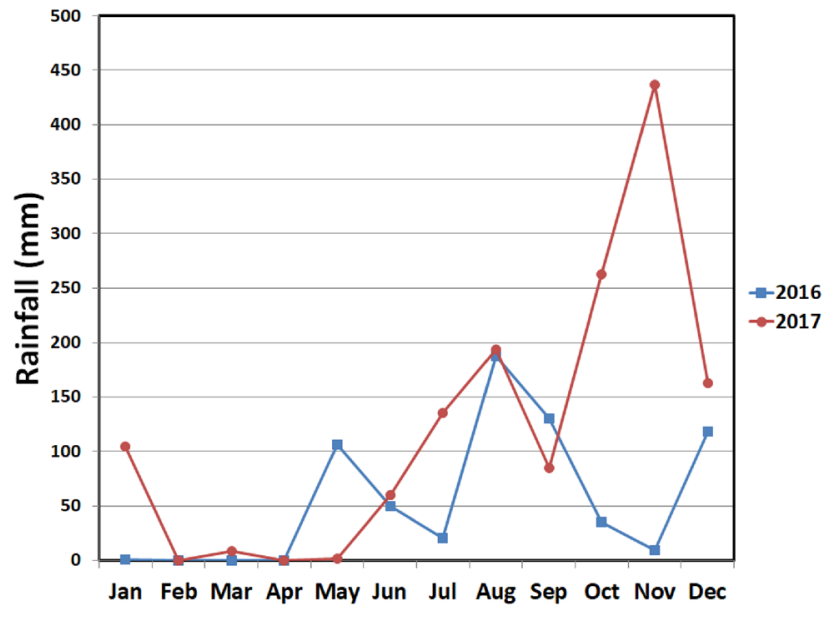

Fig. 4 Monthly rainfall in millimeter for the year 2016 and 2017

$2367 \mathrm{mg} / \mathrm{L}$; higher TDS is observed in Thavalakuppam. $59 \%$ of the samples in NEM exceed the permissible limit of TDS [65]. Around $62 \%$ of samples have higher TDS values than the acceptable limit in SWM, and maximum TDS was noted at Ellaipillaichavadi.

The physico-chemical parameters of groundwater were described in Table 3 for NEM. A higher concentration of ions such as $\mathrm{Na}, \mathrm{Cl}, \mathrm{K}, \mathrm{Ca}, \mathrm{Mg}, \mathrm{NO}_{3}$ and high $\mathrm{EC}[66,67]$ shows the influence of sea water into the aquifer. Calcium level in the samples varies from 20 to $228 \mathrm{mg} / \mathrm{L}$ during NEM and from 16 to $124 \mathrm{mg} / \mathrm{L}$ during SWM. The maximum desirable limit [65] for Ca is $75 \mathrm{mg} / \mathrm{L}$. $37 \%$ of total samples are above the desirable level; Kadaperikuppam is the location with the higher Ca during NEM. The magnesium in the samples ranges between $\mathrm{BDL}$ and $84 \mathrm{mg} / \mathrm{L}$ during NEM and 2.4 to $84 \mathrm{mg} / \mathrm{L}$ during SWM. The concentration of $\mathrm{Na}$ above permissible level of $200 \mathrm{mg} / \mathrm{L}$ leads to salted taste and also health hazards [67]; 37 percent of NEM samples are above the WHO standard. The sodium concentration varies from 11 to $561 \mathrm{mg} / \mathrm{L}$. Korakeni is the location with higher Na concentration during NEM. The sodium in the study area aquifer is mainly due to the saline sources [68]. In SWM, Na ranges between 43 and $394 \mathrm{mg} / \mathrm{L}$, and higher value is represented in Madukarai location. $49 \%$ of total sample are higher than the admissible limit of $\mathrm{Na}$ in SWM. Potassium in groundwater samples during NEM ranges between $\mathrm{BDL}$ and $88 \mathrm{mg} / \mathrm{L}$ and in SWM ranges between 2 and $248 \mathrm{mg} / \mathrm{L}$. Extensive use of agriculture fertilizer leads to high $\mathrm{K}$ in study region aquifer. According to WHO [65], $6 \%$ of samples during NEM and $9 \%$ during SWM have $\mathrm{NO}_{3}$ greater than the $45 \mathrm{mg} / \mathrm{L}$. The concentration of $\mathrm{Cl}^{-}$in groundwater samples shows that $41 \%$ exceed the permissible limit in SWM and $70 \%$ of total samples exceed the permissible limit in NEM. The higher level of $\mathrm{Cl}$ and $\mathrm{EC}$ in the groundwater reflects the influence of sea water intrusion $[69,70]$. The silica content in groundwater of study area ranges between 2 and $265 \mathrm{mg} / \mathrm{L}$ during NEM and 33 and $258 \mathrm{mg} / \mathrm{L}$ during SWM. Higher silica was observed in NEM.

The variation in EC value depends upon all the ion concentration in the groundwater; essentially, it is influenced by $\mathrm{Cl}^{-}$concentration. Three regions were identified in Fig. 5 based upon $\mathrm{EC}$ and $\mathrm{Cl}$ value, i.e., mixing zone, strong mixing (intrusion) and freshwater zone. Chlorine (above $250 \mathrm{mg} / \mathrm{L}$ ) and EC (above $1400 \mu \mathrm{S} / \mathrm{cm}$ ) present in the groundwater samples were influenced by infiltration of saltwater. These samples were categorized with an EC of 1400 and $2400 \mu \mathrm{S} / \mathrm{cm}$ as a mixture of saltwater and freshwater. The seawater signature is defined by samples with EC more than $2400 \mu \mathrm{S} / \mathrm{cm}$. Most of the samples have higher $\mathrm{EC}$ and $\mathrm{Cl}^{-}$during NEM which reflects saline nature of groundwater (Fig. 5a). Approximately $38 \%$ of samples were represented in $\mathrm{Ca}-\mathrm{Mg}-\mathrm{Cl}$ and $\mathrm{Na}-\mathrm{Cl}$ class with greater $\mathrm{EC}$ and $\mathrm{Cl}^{-}$during SWM (Fig. 5b). In the southwest and southeast region, the groundwater quality was observed to be good, with lower EC values. In the northwest and northeastern portions of the study zone, higher EC (greater than $3000 \mu \mathrm{S} / \mathrm{cm}$ ) concentrations were observed (Fig. 6) and it is noted that the samples were extremely contaminated by saline intrusion. SWM

Table 3 Evaluation of physico-chemical parameters of collected groundwater samples (all values in $\mathrm{mg} / \mathrm{l}$ except $\mathrm{pH}$, temperature $\left({ }^{\circ} \mathrm{C}\right)$ and $\mathrm{EC}(\mu \mathrm{S} / \mathrm{cm}))$. The numbers in bold indicate the highest value recorded

\begin{tabular}{|c|c|c|c|c|c|c|c|c|c|c|c|c|c|c|}
\hline & & $\mathrm{pH}$ & $\mathrm{EC}$ & TDS & $\mathrm{Ca}^{2+}$ & $\mathrm{Mg}^{+}$ & $\mathrm{Na}^{+}$ & $\mathrm{K}^{+}$ & $\mathrm{Cl}^{-}$ & $\mathrm{HCO}_{3}^{-}$ & $\mathrm{SO}_{4}{ }^{2-}$ & $\mathrm{PO}_{4}^{2-}$ & $\mathrm{Si}$ & $\mathrm{NO}_{3}$ \\
\hline \multirow[t]{3}{*}{$\operatorname{NEM}(N=68)$} & Max & 7.9 & 3830 & 2367 & 228 & 84 & 561 & 88 & 914.3 & 512.4 & 2.5 & 11.9 & 265 & 65.1 \\
\hline & Min & 6.7 & 469 & 310.2 & 20 & 2.4 & 11.4 & 0.5 & 53.2 & 24.4 & 0 & 0 & 6 & 0 \\
\hline & Avg & 7.3 & 1774 & 1126 & 92.4 & 19.4 & 173.6 & 25.7 & 357.2 & 270 & 0.4 & 0.6 & 123.4 & 13.1 \\
\hline \multirow[t]{3}{*}{ SWM $(N=68)$} & Max & 9.5 & 2343 & 1773 & 124 & 84 & 394.3 & 247.8 & 514.03 & 597.8 & 0.99 & 17.98 & 258 & 184.1 \\
\hline & Min & 5.2 & 751 & 494.2 & 16 & 2.4 & 42.7 & 1.7 & 68.63 & 73.2 & 0.03 & 0 & 33 & 0 \\
\hline & Avg & 6.8 & 1476 & 1046 & 63.3 & 23.3 & 190.1 & 30.78 & 250.8 & 320.9 & 0.52 & 1.02 & 143.2 & 16.2 \\
\hline WHO (66) & & $6.5-8.5$ & 1400 & 1000 & 100 & 50 & 200 & 20 & 250 & 300 & 250 & & & 50 \\
\hline
\end{tabular}


Fig. 5 a Relationship of chloride with EC in categorizing the fresh water (FW), sea water intrusion (SW) and mixing ( $\mathrm{FW}+\mathrm{SW}$ ) during NEM. b Relationship of chloride with EC in categorizing the fresh water (FW), sea water intrusion (SW) and mixing (FW $+\mathrm{SW})$ during SWM
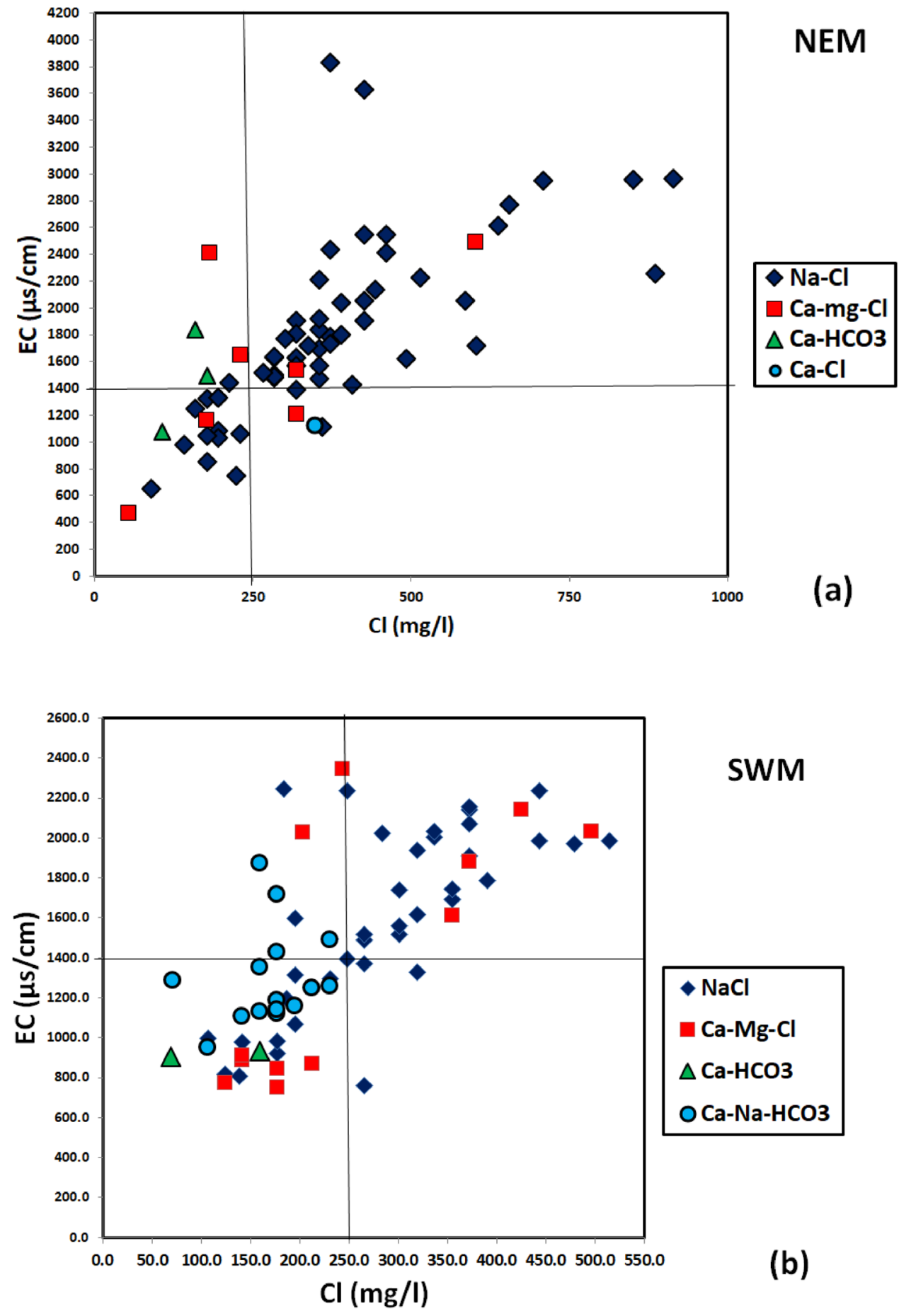

samples showed higher EC values (Fig. 7) in the southern and central parts of the study region.

The $\mathrm{Ca}-\mathrm{Mg}-\mathrm{Cl}$ and $\mathrm{Na}-\mathrm{Cl}$ are the significant water types noted (Fig. 8a) during NEM. Most of the samples have high sodium and chloride, inferring the removal of other minor ions from the water through either adsorption or by precipitation $[71,72]$ due to saturation or infiltration of seawater [63]. Migration of samples from mixed $\mathrm{Ca}-\mathrm{Mg}-\mathrm{Cl}$ type to $\mathrm{Na}-\mathrm{Cl}$ type reflects seawater intrusion in groundwater of the study area. The intrusion of sea water is attributed to the decline in precipitation, decrease in water level and extensive groundwater use. The saline water intrusion in this region is also attributed to rigorous use of groundwater for domestic purposes, thus increasing $\mathrm{Na}$ with respect to $\mathrm{Ca}$ and $\mathrm{Mg}$ in cations; $\mathrm{Cl}$ exceeds $\mathrm{HCO}_{3}$ and $\mathrm{SO}_{4}$ in anions [73]. In the discharge zone, the $\mathrm{Na}-\mathrm{Cl}$ type of water is 


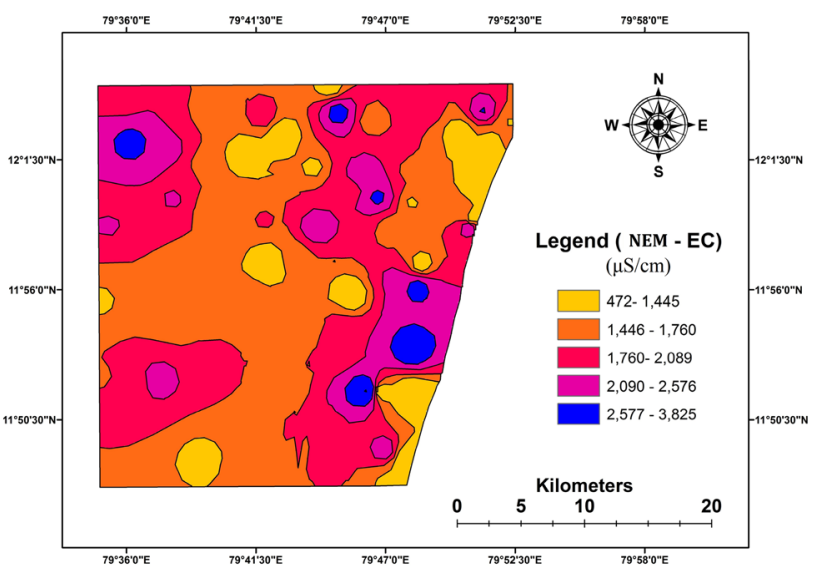

Fig. 6 Spatial distribution of EC $(\mu \mathrm{S} / \mathrm{cm})$ for groundwater samples collected during NEM

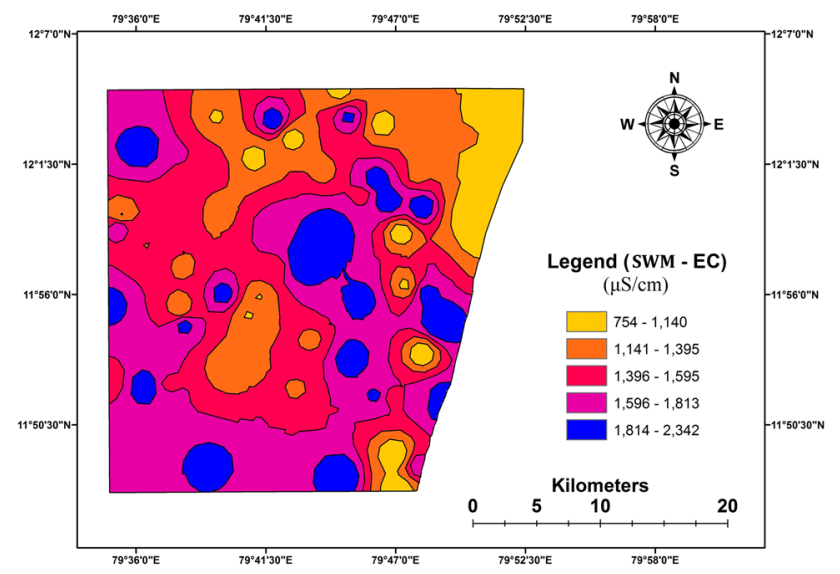

Fig. 7 Spatial distribution of EC $(\mu \mathrm{S} / \mathrm{cm})$ for groundwater samples collected during SWM

noted [74]. During SWM, most of the samples (Fig. 8b) fall within the $\mathrm{Na}-\mathrm{Cl}$ and $\mathrm{Ca}-\mathrm{Na}-\mathrm{HCO}_{3}$ water type. Few samples in SWM fall in the zone of the $\mathrm{Ca}-\mathrm{Mg}-\mathrm{Cl}$ type representing rock-water interaction and ion exchange reaction $[73,75]$. The decline of $\mathrm{Na}$ and $\mathrm{Cl}$ percentage with increasing salinity is primarily an effect of $\mathrm{Na}$ reduction due to reverse ion exchange $[73,75]$. The occurrence of reverse ion exchange in the study area is also manifested from the Chadha diagram. In both the NEM and SWM seasons, $\mathrm{Na}$ and $\mathrm{Cl}$ are the dominant ions controlling the groundwater chemistry.

The distribution of electric conductivity is shown in Fig. 9. The groundwater is considered as freshwater if the values of EC are lower than $750 \mu \mathrm{S} / \mathrm{cm}[76,77]$. During NEM and SWM (Fig. 10), about $3 \%$ of the samples have low EC value $(<750 \mu \mathrm{S} / \mathrm{cm})$ during NEM and it is suitable for the irrigation purpose. $77 \%$ and $99 \%$ of the samples were ranging from 751 to $2250 \mu \mathrm{S} / \mathrm{cm}$ during NEM and SWM,
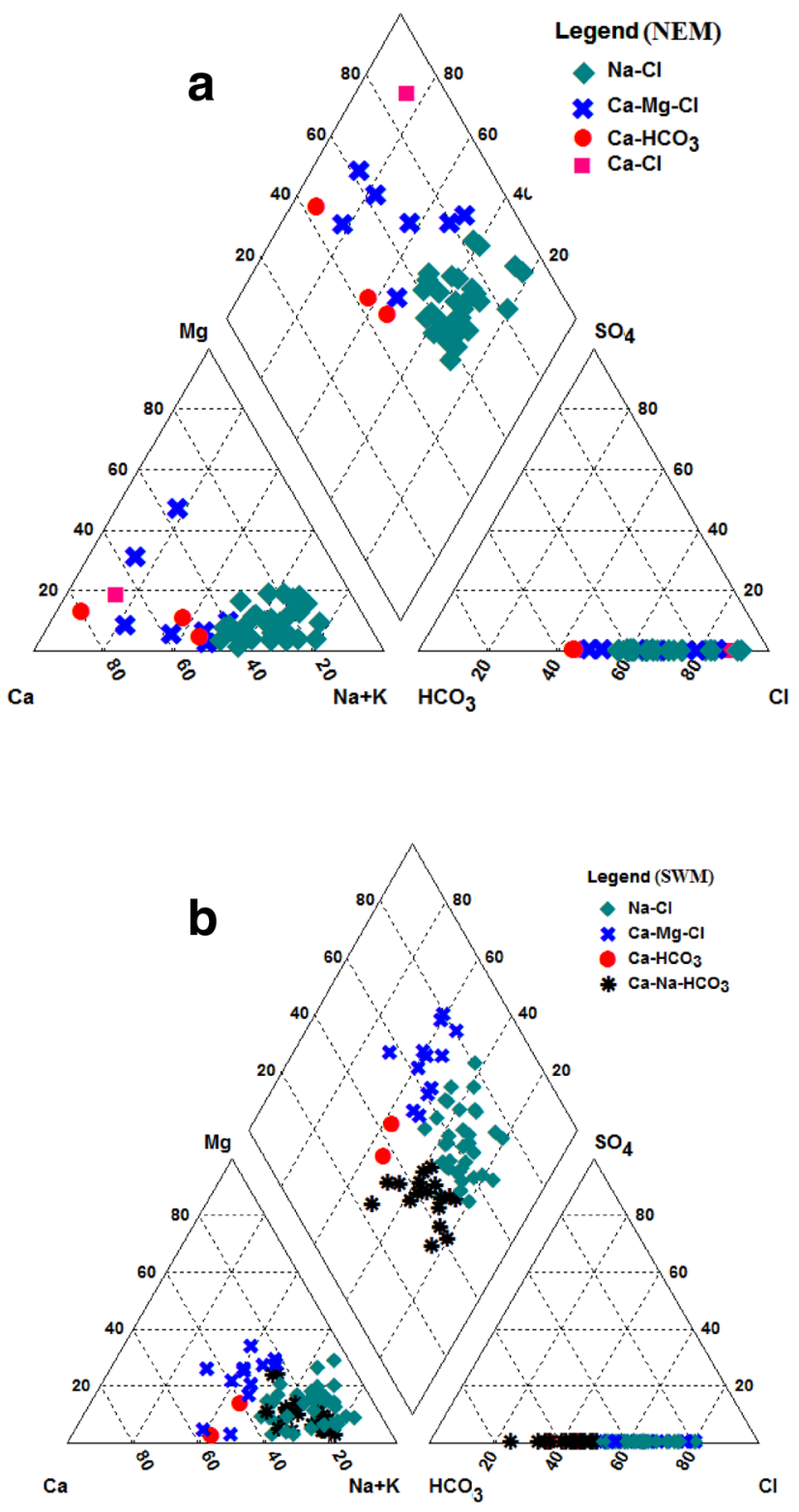

Fig. 8 a Major water types of the water samples during NEM are depicted in the Piper diagram. b Major water types of the water samples during SWM are depicted in the Piper diagram

respectively, representing doubtful for irrigation [78-81]. The 17 percent and 1 percent of samples during NEM and SWM show that EC ranges between 2251 and $3000 \mu \mathrm{S} / \mathrm{cm}$ and about 3 percent of groundwater sampling wells were observed to have EC values $>3000 \mu \mathrm{S} / \mathrm{cm}$ during NEM. The samples of above $2250 \mu \mathrm{S} / \mathrm{cm}$ EC are not suitable for irrigation [76].

\subsection{Ionic Ratios}

A hydrochemical graph is [82] considered in this study to interpret the hydrochemical processes that occur within 


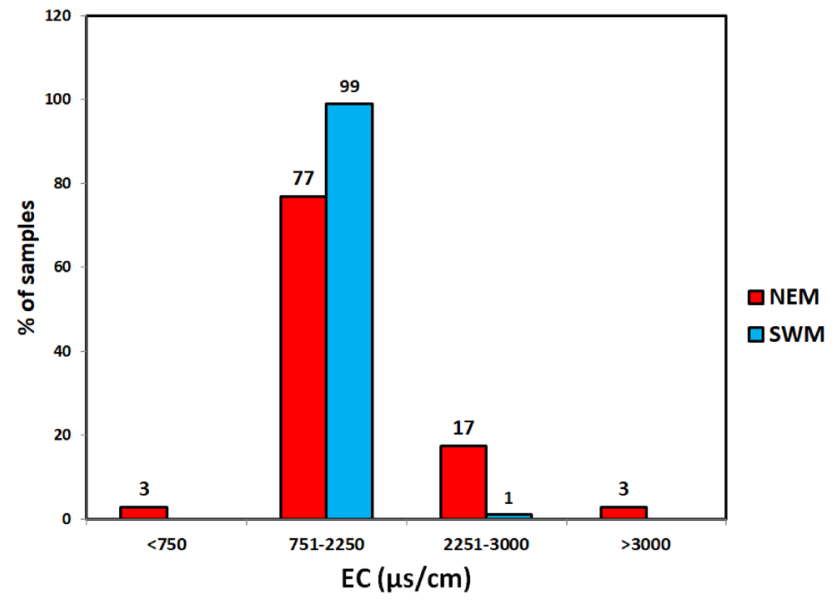

Fig. 9 EC Variations in groundwater representing different ranges with respect to season

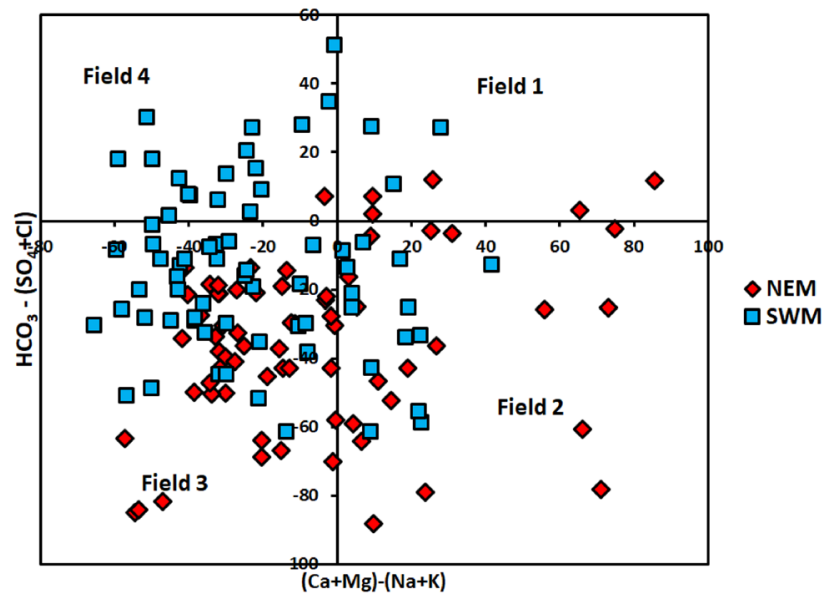

Fig. 10 Geochemical process evaluation plot for groundwater samples (after Chadha [82])

the study area. The same method was effectively associated with a coastal aquifer $[83,84]$ to classify the two distinctive hydrogeochemical processes. During NEM, the maximum numbers of samples are observed in Field 3 (Na$\mathrm{Cl}$ ) (Fig. 10) which indicates influence of seawater mixing and is usually bound to the coastal zones. Field 1 (recharging water) contains only few samples. Regardless of the samples with reverse ion exchange in field 2 , the process of base ion exchange in water is indicated in field 4 (Na$\mathrm{HCO}_{3}$ ) in few samples. During SWM, the predominance of samples in Fields $3(\mathrm{Na}-\mathrm{Cl})$ and $4\left(\mathrm{Na}-\mathrm{HCO}_{3}\right)$ reflects reverse ion exchange (Field 2) and recharge waters (Field 1) during SWM (Fig. 10). The samples near to the coastal zone have high $\mathrm{Cl}$ and $\mathrm{Na}^{+}$, hence predominantly falls within Field 3 with less representation in Field 2. Moreover, most of the samples representing a high $\mathrm{Na}$ and $\mathrm{Cl}$, also represent a high concentration of $\mathrm{Ca}, \mathrm{Mg}, \mathrm{HCO}_{3}, \mathrm{Cl}$ and $\mathrm{SO}_{4}$ reflecting ion exchange process. Thus, it can be inferred that reverse ion exchange is also a key process responsible for the hydrochemical variation in the study area during NEM and SWM [85]. However, ion exchange process is more dominant in SWM compared with NEM.

To understand the saltwater intrusion process, the $\mathrm{Cl}^{-}$-to- $\mathrm{Na}^{+}$ionic ratio was considered. The $\mathrm{Na} / \mathrm{Cl}$ ratios for groundwater samples show that most of the SWM samples exceed the ratio of seawater (0.88) and that of the NEM samples are marginally greater than the value (Fig. 11 a). The higher value of the ratio indicates the predominance of $\mathrm{Na}$ to $\mathrm{Cl}$ indicating the influence of fresh water during SWM (Fig. 11b) and highlighting the recharge region suggesting the freshwater in the aquifer. The values lower than the seawater ratio may be due to the replacement of cations due to the ion exchange process subsequent to the seawater intrusion into the freshwater aquifers which

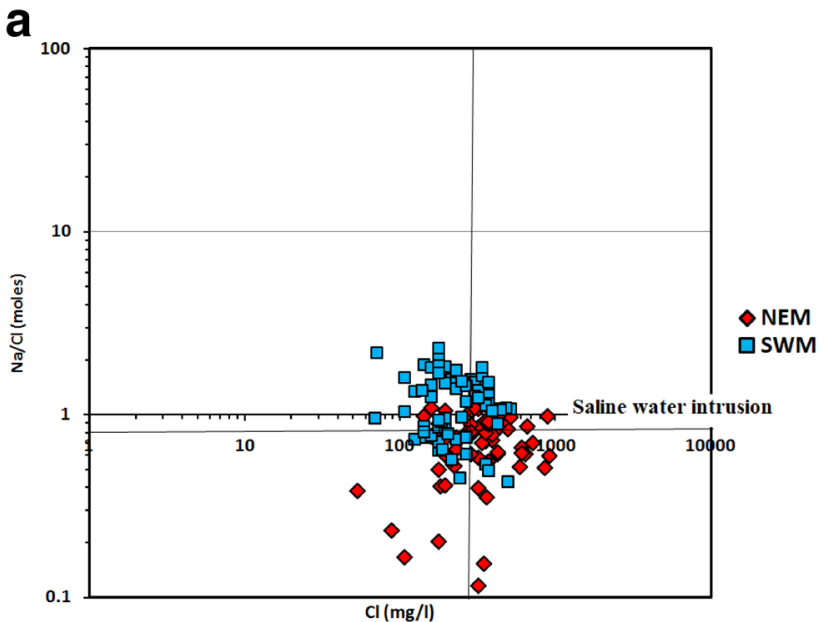

b

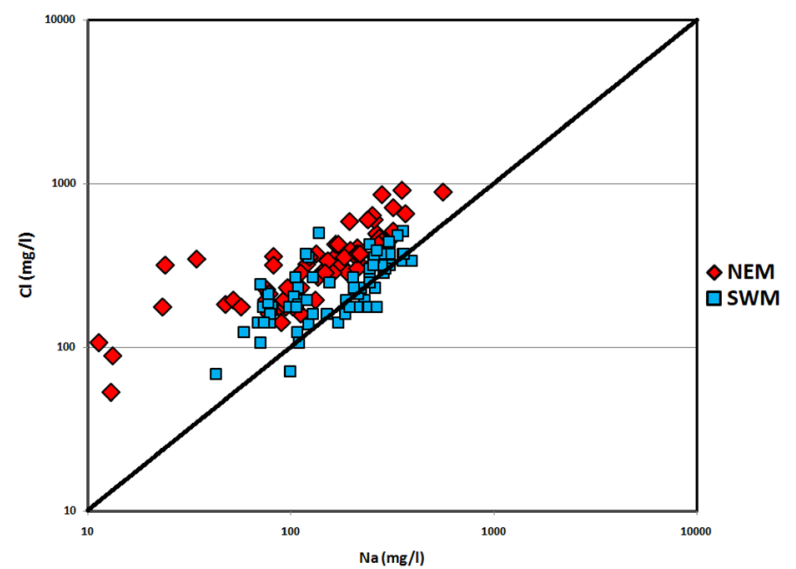

Fig. 11 a The relationship between the $\mathrm{Na}^{+} / \mathrm{Cl}^{-}$ratio and the $\mathrm{Cl}^{-}$values to determine the saline intrusion. $\mathbf{b}$. The bivariate plot between the $\mathrm{Na}$ and $\mathrm{Cl}$ to determine the sea water intrusion process 
are consequential in a reduction of the surplus of $\mathrm{Na}$ and Ca.

As shown in Table $4,21 \%$ of NEM samples and $10 \%$ of SWM samples show elevated $\mathrm{Na} / \mathrm{Cl}$, and it is also observed that the $53 \%$ of NEM samples and $77 \%$ of SWM samples have ratios of $\mathrm{Ca} /\left(\mathrm{HCO}_{3}+\mathrm{SO}_{4}\right)$ greater than unity [86].

The disgraceful management and transfer of household wastewater may be the major cause of salinization within the coastal aquifer during SWM [87]. The groundwater samples contaminated by sewage effluent have $\mathrm{Na} / \mathrm{Cl}$ value greater than unity and comparatively higher than $\mathrm{SO}_{4} / \mathrm{Cl}(0.09)$ [88]. The higher values of these ratios are due to intensive use of $\mathrm{NaCl}$ salts and residential wastewater infiltration. The lower $\mathrm{K} / \mathrm{Cl}$ values in the shallow aquifers indicate an anthropogenic impact. Source of $\mathrm{K}$ is mainly anthropogenic which is supported by the $\mathrm{K} / \mathrm{Cl}$ ratio; 13 percent and 18 percent of the samples during NEM and SWM, respectively, reflect the anthropogenic influence. $\mathrm{The} \mathrm{Ca} /\left(\mathrm{HCO}_{3}+\mathrm{SO}_{4}\right)$ ratio indicates the influence of saltwater intrusion in the study area.

\subsection{Statistical analysis}

\subsubsection{Correlation matrix}

Correlation matrix (Table 5) describes the inter-relation among the variables to identify the source of contaminates in the groundwater. Positive correlation is observed between $\mathrm{pH}, \mathrm{EC}, \mathrm{TDS} \mathrm{Na}, \mathrm{Cl}$, and $\mathrm{HCO}_{3}$ during NEM. Strong positive correlation among $\mathrm{EC}$ and TDS with ions of $\mathrm{Na}, \mathrm{Cl}$ and $\mathrm{HCO}_{3}$ reflects the influence of these ions to increase the $\mathrm{EC}$ and TDS values. $\mathrm{Cl}$ shows positive correlation with $\mathrm{Na}$ indicating the influence of sea water intrusion and secondary leaching of salts $[62,89]$. During SWM, $\mathrm{pH}$ is positively correlated with $\mathrm{HCO}_{3}$. Strong positive correlation is observed among EC, TDS and Na. Likewise, the good correlation between $\mathrm{Na}$ and $\mathrm{Cl}$ indicates percolating of secondary salts and impact of the saltwater in the groundwater of the study area [62]. Mg also has good correlation with $\mathrm{Cl}$. In general, there is a good correlation existing between $\mathrm{Na}$ and $\mathrm{Cl}$ in both the NEM and SWM seasons which indicates

Table 4 Range of ionic ratio in sea water compared to the NEM and SWM samples to determine the seawater intrusion

\begin{tabular}{llcc}
\hline & $\begin{array}{l}\text { Sea water } \\
\text { intrusion }\end{array}$ & NEM (\%) & SWM (\%) \\
\hline $\mathrm{Na}^{+} / \mathrm{Cl}^{-}$ & $0.86-1$ & 20.6 & 10.3 \\
$\mathrm{~K}^{+} / \mathrm{Cl}^{-}$ & 0.05 & 13.2 & 17.6 \\
$\mathrm{SO}_{4}{ }^{2-} / \mathrm{Cl}^{-}$ & 0.02 & 0.0 & 0.0 \\
$\mathrm{Mg}^{+} / \mathrm{Ca}^{2+}$ & $>5$ & 0.0 & 0.0 \\
$\mathrm{Ca}^{2+} /\left(\mathrm{HCO}_{3}{ }^{-}+\mathrm{SO}_{4}{ }^{2-}\right)$ & $0.35-1$ & 52.9 & 76.5 \\
\hline
\end{tabular}

a strong influence of sea water on the groundwater of the study area especially in the samples located in the coastal region.

\subsubsection{Factor Analysis}

To identify the processes responsible for the groundwater contamination of the study area, factor analysis (PCA) was carried out. There were four factors extracted during NEM and five factors during SWM (Table 6 and 7).

Factor I with strong positive loading of $\mathrm{Na}, \mathrm{K}, \mathrm{Cl}, \mathrm{HCO}_{3}$, EC and TDS (Table 6) could be linked to the saline source during NEM $[90,91]$. The factor II with strong positive loading of $\mathrm{pH}, \mathrm{HCO}_{3}$ and $\mathrm{SO}_{4}$ is typically influenced by the contaminant from agricultural activities [58]. The chemical weathering or silicate dissolution might be related to high Si in factor III [92]. Similarly, in factor IV, there is a positive loading of $\mathrm{Ca}$ and $\mathrm{Mg}$ with very low loading of $\mathrm{Na}$ and $\mathrm{K}$, which clearly implies the base ion exchange process. The factor I with positive loading of $\mathrm{Mg}, \mathrm{Na}, \mathrm{Cl}$, TDS and EC (Table 7) is linked to percolation of secondary salts during SWM $[60,71]$ deposited in the pore spaces during previous summer. The factor $\mathrm{Il}$, with a positive loading of $\mathrm{K}$ and $\mathrm{PO}_{4}$, indicates the influence of anthropogenic sources mainly from agricultural activities [93]. The positive loading of factor III with $\mathrm{Na}^{+}$and $\mathrm{HCO}_{3}$ indicates weathering process [94]. The high loading of $\mathrm{NO}_{3}$ in factor IV could be related to impact of fertilizers applied in farming lands. The positive loading of $\mathrm{Ca}$ and $\mathrm{SO}_{4}$ in factor $\mathrm{V}$ is due to anthropogenic activities [95].

\section{Conclusion}

Intensive groundwater extraction in the study area has resulted in saline water intrusion into the aquifer. The shallow aquifer signifies less resistivity, which might be due to dominant clay layers or seawater intrusion in southeast regions. Rainfall plays an important role in water level fluctuation. Reduction in amount of rainfall during SWM of 2016, has led to the saline water intrusion in the deeper aquifers of the study area. Higher values of EC were noted in the groundwater samples of NEM. The hydrochemistry shows that TDS values are higher and above the standard limits for most of the samples with $59 \%$ and $62 \%$ of both NEM and SWM samples, considered unsuitable for drinking purposes. The spatial representation of the EC values shows that the groundwater samples are more saline during NEM and are represented along the southeastern part of the study region. The $\mathrm{Na}-\mathrm{Cl}$ and $\mathrm{Ca}-\mathrm{Mg}-\mathrm{Cl}$ are the dominant water types in the groundwater samples during $\mathrm{NEM}$, and representation of $\mathrm{Cl}-\mathrm{HCO}_{3}$ type is noted in the SWM, indicating the recharge process. Seasonal variation 
Table 5 Correlation analysis of groundwater samples for NEM and SWM (numbers in italics indicate the correlation coefficient of SWM samples; numbers in bold indicates the good to significant positive correlation)

\begin{tabular}{|c|c|c|c|c|c|c|c|c|c|c|c|c|c|c|}
\hline & $\mathrm{Ca}$ & $\mathrm{Mg}$ & $\mathrm{Na}$ & K & $\mathrm{Cl}$ & $\mathrm{HCO}_{3}$ & $\mathrm{NO}_{3}$ & $\mathrm{PO}_{4}$ & $\mathrm{SO}_{4}$ & $\mathrm{Si}$ & TDS & $\mathrm{EC}$ & temp & $\mathrm{pH}$ \\
\hline \multirow[t]{2}{*}{$\mathrm{Ca}$} & 1 & & & & & & & & & & & & & \\
\hline & 1 & & & & & & & & & & & & & \\
\hline \multirow[t]{2}{*}{$\mathrm{Mg}$} & -0.18 & 1 & & & & & & & & & & & & \\
\hline & 0.08 & 1 & & & & & & & & & & & & \\
\hline \multirow[t]{2}{*}{$\mathrm{Na}$} & 0.14 & 0.20 & 1 & & & & & & & & & & & \\
\hline & 0.01 & 0.31 & 1 & & & & & & & & & & & \\
\hline \multirow[t]{2}{*}{ K } & 0.06 & 0.25 & 0.46 & 1 & & & & & & & & & & \\
\hline & -0.08 & 0.01 & 0.09 & 1 & & & & & & & & & & \\
\hline \multirow[t]{2}{*}{$\mathrm{Cl}$} & 0.36 & 0.36 & 0.83 & 0.41 & 1 & & & & & & & & & \\
\hline & 0.26 & 0.61 & 0.69 & 0.11 & 1 & & & & & & & & & \\
\hline \multirow[t]{2}{*}{$\mathrm{HCO}_{3}$} & 0.16 & 0.28 & 0.48 & 0.46 & 0.26 & 1 & & & & & & & & \\
\hline & 0.23 & 0.28 & 0.65 & 0.22 & 0.26 & 1 & & & & & & & & \\
\hline \multirow[t]{2}{*}{$\mathrm{NO}_{3}$} & -0.11 & 0.20 & 0.30 & 0.24 & 0.17 & 0.17 & 1 & & & & & & & \\
\hline & 0.12 & 0.22 & 0.17 & 0.35 & 0.22 & 0.18 & 1 & & & & & & & \\
\hline \multirow[t]{2}{*}{$\mathrm{PO}_{4}$} & -0.13 & -0.09 & -0.18 & -0.18 & -0.21 & -0.16 & 0.11 & 1 & & & & & & \\
\hline & -0.01 & -0.10 & 0.008 & 0.45 & -0.004 & 0.05 & 0.01 & 1 & & & & & & \\
\hline \multirow[t]{2}{*}{$\mathrm{SO}_{4}$} & 0.12 & -0.15 & 0.07 & 0.05 & -0.06 & 0.18 & -0.04 & 0.03 & 1 & & & & & \\
\hline & 0.33 & 0.22 & 0.20 & 0.09 & 0.33 & 0.19 & 0.24 & 0.01 & 1 & & & & & \\
\hline \multirow[t]{2}{*}{ Si } & 0.09 & 0.09 & 0.02 & 0.10 & 0.10 & 0.14 & -0.27 & -0.23 & -0.007 & 1 & & & & \\
\hline & 0.09 & 0.07 & -0.01 & -0.25 & 0.12 & -0.13 & -0.09 & -0.16 & -0.005 & 1 & & & & \\
\hline \multirow[t]{2}{*}{ TDS } & 0.33 & 0.35 & 0.65 & 0.47 & 0.66 & 0.62 & 0.28 & -0.26 & 0.06 & 0.09 & 1 & & & \\
\hline & 0.31 & 0.53 & 0.82 & 0.27 & 0.77 & 0.75 & 0.37 & 0.07 & 0.39 & 0.07 & 1 & & & \\
\hline \multirow[t]{2}{*}{ EC } & 0.33 & 0.34 & 0.70 & 0.49 & 0.69 & 0.62 & 0.35 & -0.26 & 0.06 & 0.02 & 0.98 & 1 & & \\
\hline & 0.22 & 0.49 & 0.59 & 0.22 & 0.72 & 0.44 & 0.41 & 0.08 & 0.36 & 0.11 & 0.82 & 1 & & \\
\hline \multirow[t]{2}{*}{ temp } & 0.12 & -0.08 & -0.18 & -0.05 & 0.02 & -0.28 & -0.21 & -0.03 & 0.007 & 0.05 & -0.24 & -0.26 & 1 & \\
\hline & -0.02 & 0.10 & 0.24 & 0.08 & 0.11 & 0.32 & 0.32 & -0.24 & -0.01 & 0.23 & 0.26 & 0.18 & 1 & \\
\hline \multirow[t]{2}{*}{$\mathrm{pH}$} & 0.18 & 0.08 & 0.09 & 0.10 & -0.03 & 0.57 & -0.05 & -0.09 & 0.26 & 0.15 & 0.21 & 0.20 & -0.09 & 1 \\
\hline & -0.14 & -0.01 & -0.15 & -0.08 & -0.02 & -0.32 & 0.05 & -0.12 & -0.18 & 0.03 & -0.26 & -0.17 & 0.19 & 1 \\
\hline
\end{tabular}

in groundwater salinity was observed during seasons. The inverse ion exchange process also plays a vital role in hydrochemical variation in groundwater during both the seasons. The factor analysis shows that the major factors which influence the groundwater quality of the study area are anthropogenic activities, ion exchange process and saline water intrusion. The process of seawater intrusion is substantiated by positive loadings of $\mathrm{Na}$ and $\mathrm{Cl}$ in both NEM and SWM samples. Though the salinity of SWM monsoon samples are higher, the ratios and ion relationships indicate that the leaching of salts plays a major role in the geochemistry of SWM samples apart from sea water intrusion. The NEM samples are mainly influenced by the sea water intrusion due to higher extraction for agricultural practices and failure of NEM. The samples of NEM also reflect signature of fertilizers and ion exchange process. Hence, integrating the results of lithologs, resistivity values, rainfall and water level variation along with the groundwater geochemistry the study infers that the groundwater along the southeastern part are more influenced by the sea water intrusion irrespective of the season. Further with more detailed analysis, including isotopes and trace elements will provide a more vivid picture, corroborating with the conclusion derived from the present study. The time series analysis of the available geochemical data, trend of rainfall, freshwater demand, increase in population, change in landuse pattern would provide a lucid management solution for the resource. 
Table 6 Factor scores of GW samples and varimax factor matrix of chemical constituents during NEM (numbers in bold indicates the positive loadings of the parameters in the factor)

\begin{tabular}{lrrrr}
\hline $\mathrm{NEM}$ & \multicolumn{3}{l}{2} & \multicolumn{2}{l}{ l } \\
\hline $\mathrm{Ca}^{2+}$ & 0.36 & 0.09 & 0.17 & 0.72 \\
$\mathrm{Mg}^{+}$ & 0.38 & -0.01 & 0.18 & 0.63 \\
$\mathrm{Na}^{+}$ & $\mathbf{0 . 8 4}$ & 0.05 & -0.06 & 0.01 \\
$\mathrm{~K}^{+}$ & $\mathbf{0 . 5 9}$ & 0.14 & 0.09 & -0.19 \\
$\mathrm{Cl}^{-}$ & $\mathbf{0 . 8 8}$ & -0.21 & 0.12 & 0.10 \\
$\mathrm{HCO}_{3}{ }^{-}$ & $\mathbf{0 . 5 2}$ & $\mathbf{0 . 7 0}$ & 0.09 & -0.17 \\
$\mathrm{NO}_{3}$ & 0.39 & -0.002 & -0.59 & -0.31 \\
$\mathrm{PO}_{4}$ & -0.28 & 0.005 & -0.57 & 0.006 \\
$\mathrm{SO}_{4}$ & -0.02 & $\mathbf{0 . 5 5}$ & -0.13 & 0.41 \\
$\mathrm{Si}$ & 0.02 & 0.12 & $\mathbf{0 . 7 6}$ & -0.09 \\
$\mathrm{TDS}_{\mathrm{EC}}$ & $\mathbf{0 . 8 8}$ & 0.24 & 0.04 & -0.02 \\
temp & $\mathbf{0 . 9 1}$ & 0.23 & -0.03 & -0.02 \\
$\mathrm{pH}$ & -0.14 & -0.38 & 0.32 & 0.39 \\
Initial eigenvalues of variance & 30.65 & 13.02 & 11.05 & 10.33 \\
$\quad$ explained by each other (in & & & & \\
$\quad$ \%) & & & & \\
Cumulative of variance (in \%) & 30.65 & 43.67 & 54.73 & 65.06 \\
\hline
\end{tabular}

Table 7 Factor scores of GW samples and varimax factor matrix of chemical constituents during SWM (numbers in bold indicates the positive loadings of the parameters in the factor)

\begin{tabular}{llllll}
\hline SWM & 1 & 2 & 3 & 4 & 5 \\
\hline $\mathrm{Ca}^{2+}$ & 0.05 & -0.16 & 0.15 & -0.006 & $\mathbf{0 . 8 0}$ \\
$\mathrm{Mg}^{+}$ & $\mathbf{0 . 7 5}$ & -0.10 & -0.08 & 0.02 & 0.06 \\
$\mathrm{Na}^{+}$ & $\mathbf{0 . 7 0}$ & 0.002 & $\mathbf{0 . 5 4}$ & 0.14 & -0.14 \\
$\mathrm{~K}^{+}$ & 0.11 & $\mathbf{0 . 7 9}$ & 0.04 & 0.31 & 0.01 \\
$\mathrm{Cl}^{-}$ & $\mathbf{0 . 9 1}$ & -0.04 & 0.03 & 0.002 & 0.16 \\
$\mathrm{HCO}_{3}{ }^{-}$ & 0.31 & 0.10 & $\mathbf{0 . 8 0}$ & 0.29 & 0.07 \\
$\mathrm{NO}_{3}$ & 0.23 & 0.30 & -0.14 & $\mathbf{0 . 6 8}$ & 0.33 \\
$\mathrm{PO}_{4}{ }^{2-}$ & 0.04 & $\mathbf{0 . 7 4}$ & 0.008 & -0.23 & 0.008 \\
$\mathrm{SO}_{4}$ & 0.27 & 0.07 & 0.05 & 0.03 & $\mathbf{0 . 7 0}$ \\
$\mathrm{Si}$ & 0.15 & -0.58 & -0.13 & 0.06 & 0.08 \\
$\mathrm{TDS}^{2}$ & $\mathbf{0 . 7 8}$ & 0.09 & 0.49 & 0.23 & 0.23 \\
$\mathrm{EC}$ & $\mathbf{0 . 7 8}$ & 0.11 & 0.18 & 0.18 & 0.25 \\
Temp & 0.08 & -0.26 & 0.16 & $\mathbf{0 . 8 3}$ & -0.13 \\
$\mathrm{pH}$ & 0.03 & -0.13 & -0.66 & 0.32 & -0.28 \\
Initial eigenvalues of vari- & 24.5 & 12.71 & 12.63 & 11.66 & 10.97 \\
$\quad$ ance explained by each & & & & & \\
$\quad$ other (in \%) & & & & & \\
Cumulative of variance & 24.5 & 37.2 & 49.90 & 61.56 & 72.53 \\
$\quad$ (in \%) & & & & & \\
\hline
\end{tabular}

Funding This research was financially sponsored by the Commission on University Grants (UGC) No. F.151/2016-17/ PDFWM-2015-17-TAM-34825(SA-II).

\section{Compliance with ethical standards}

Conflict of interest On behalf of all authors, the corresponding author states that there is no conflict of interest.

Open Access This article is licensed under a Creative Commons Attribution 4.0 International License, which permits use, sharing, adaptation, distribution and reproduction in any medium or format, as long as you give appropriate credit to the original author(s) and the source, provide a link to the Creative Commons licence, and indicate if changes were made. The images or other third party material in this article are included in the article's Creative Commons licence, unless indicated otherwise in a credit line to the material. If material is not included in the article's Creative Commons licence and your intended use is not permitted by statutory regulation or exceeds the permitted use, you will need to obtain permission directly from the copyright holder. To view a copy of this licence, visit http://creativecommons. org/licenses/by/4.0/.

\section{References}

1. Meybeck M, Vorosmarty C, Schultze R, Becker A (2003) Conclusions: scaling relative responses of terrestrial aquatic systems to global changes. In book: Vegetation, water, humans and the climate, pp 455-464. doi: https://doi.org/10.1007/978-3-64218948-7_37.

2. Park SC, Yun ST, Chae GT, Yoo IS, Shin KS, Heo CH (2005) J Hydrol 31(3):182-194

3. Batayneh $A$ (2006) Hydrogeological Journal 14:1277-1283

4. Werner A, Simmons C (2009) Ground Water 47(2):197-204

5. Chang S, Clement T, Simpson M, Lee K (2011) Adv Water Resour 34:1283-1291

6. Masciopinto C (2006) Simulation of coastal groundwater remediation: The case of Nardò fractured aquifer in Southern Italy. Model. Softw, Environ. https://doi.org/10.1016/j.envsoft.2004. 09.028

7. Mjemah IC, Van Camp M, Walraevens K (2009) Groundwater exploitation and hydraulic parameter estimation for a Quaternary aquifer in Dar-es-Salaam. Tanzania J Afr Earth Sci 55:134146. https://doi.org/10.1016/j.jafrearsci.2009.03.009

8. Van Camp M, Mtoni YE, Mjemah IC, Bakundukize C, Walraevens K (2014) Investigating seawater intrusion due to groundwater pumping with schematic model simulations: The example of the Dar Es Salaam coastal aquifer in Tanzania. J Afr Earth Sci 96:71-78

9. Anders R, Mendez GO, Futa K, Danskin WR (2013) A Geochemical approach to determine sources and movement of saline groundwater in a coastal aquifer. Groundwater 52(5):756-768. https://doi.org/10.1111/gwat.12108

10. Nair IS, Rajaveni SP, Schneider M, Elango L (2015) Geochemical and isotopic signatures for the identification of seawater intrusion in an alluvial aquifer. J Earth SystSci 124(6):1281-1291. https://doi.org/10.1007/s12040-015-0600-y

11. Amiri V, Nakhaei M, Lak R, Kholghi M (2015) Assessment of seasonal groundwater quality and potential saltwater intrusion: a study case in Urmia coastal aquifer (NW Iran) using the groundwater quality index (GQI) and hydrochemical facies evolution diagram (HFE-D). Stoch Environ Res Risk Assess 30(5):14731484. https://doi.org/10.1007/s00477-015-1108-3 
12. Todd DK (1980) Groundwater hydrology, 2nd edn. Wiley, New York

13. Sukhija BS, Varma VN, Nagabhushanam P, Reddy DV (1996) Differentiation of paleomarine and modern seawater intruded salinities in coastal groundwaters (of Karaikal and Tanjavur, India) based on inorganic chemistry, organic biomarker fingerprints and radiocarbon dating. J Hydrol 174:173-201. https:// doi.org/10.1016/0022-1694(95)02712-2

14. Saxena VK, Singh VS, Mondal NC, Jain SC (2003) Use of chemical parameters to delineation fresh groundwater resources in Potharlanka Island. India Environm Geol 44(5):516-521. https:// doi.org/10.1007/s00254-003-0807-0

15. Beddows PA, Smart PL, Whitaker FF, Smith SL (2007) Decoupled fresh-saline groundwater circulation of a coastal carbonate aquifer: Spatial patterns of temperature and specific electrical conductivity. J Hydrol 346:18-32. https://doi.org/10.1016/j.jhydr ol.2007.08.013

16. Sarwade DV, Nandakumar MV, Kesari MP, Mondal NC, Singh VS, Singh B (2007) Evaluation of sea water ingress into an Indian Attoll. Environ Geol 52(2):1475-1483. https://doi.org/10.1007/ s00254-006-0592-7

17. Chidambaram S, Senthil Kumar G, Prasanna MV, John Peter A, Ramanthan AL, Srinivasamoorthy K (2009) A study on the hydrogeology and hydrogeochemistry of groundwater from different depths in a coastal aquifer Annamalai Nagar Tamilnadu India. Environ Geol 57:59-73. https://doi.org/10.1007/ s00254-008-1282-4

18. Kim KY, Park YS, Kim GP, Park KH (2009) Dynamic freshwater-saline water interaction in the coastal zone of Jeju Island, South Korea. Hydrogeol J 17:617-629. https://doi.org/10.1007/ s10040-008-0372-4

19. Richter BC, Kreitler CW (1993) Geochemical techniques for identifying sources of ground-water salinization (258). CRC Press

20. Mondal NC, Singh VS, Puranik SC, Singh VP (2010) Trace element concentration in groundwater of Pesarlanka Island, Krishna Delta, India. Environ Monit Assess 163:215-227. https://doi.org/ 10.1007/s10661-009-0828-6

21. Siddha S, Sahu P (2020) A statistical approach to study the evolution of groundwater of Vishwamitri River Basin (VRB), Gujarat. J Geol Soc India 95:503-506. https://doi.org/10.1007/ s12594-020-1468-2

22. Giménez-Forcada E (2019) Use of the hydrochemical facies diagram (HFE-D) for the evaluation of salinization by seawater intrusion in the coastal Oropesa plain: comparative analysis with the coastal Vinaroz Plain. Spain HydroResearch 2:76-84

23. Boluda-Botella N, Gomis-Yagües V, Ruiz-Beviá F (2008) Influence of transport parameters and chemical properties of the sediment in experiments to measure reactive transport in seawater intrusion. J Hydrol 357:29-41. https://doi.org/10.1016/j.jhydrol. 2008.04.021

24. Giménez-Forcada E (2014) Space/time development of seawater intrusion, a study case in Vinaroz coastal plain (Eastern Spain) using HFE-diagram, and spatial distribution of hydrochemical facies. J Hydrol 517:617-627. https://doi.org/10.1016/j.jhydrol. 2014.05.056

25. Gomis-Yagües V, Boluda-Botella N, Ruiz-Beviá F (2000) Gypsum precipitation as an explanation of the decrease of $\mathrm{SO} 4$ concentration during seawater intrusion. J Hydrol 228:48-55. https:// doi.org/10.1016/S0022-1694(99)00207-3

26. Giménez-Forcada E (2010) Dynamic of seawater interface using hydrochemical facies evolution diagram. Ground Water 48(2):212-216. https://doi.org/10.1111/j.1745-6584.2009. 00649.x

27. Giménez-Forcada E, Sánchez San Román FJ (2015) An excel macro to plot the HFE-diagram to identify sea water intrusion phases. Groundwater 53(5):819-824. https://doi.org/10.1111/ gwat. 12280

28. Ghiglieri G, Carletti A, Pittalis D (2012) Analysis of salinization processes in the coastal carbonate aquifer of Porto Torres (NW Sardinia, Italy). J Hydrol 432-433:43-51. https://doi.org/10. 1016/j.jhydrol.2012.02.016

29. Liu Q, Li F, Zhang Q, Li J, Zhang Y, Tu C, Ouyang Z (2014) Impact of water diversion on the hydrogeochemical characterization of surface water and groundwater in the Yellow River Delta Appl. Geochem 48:83-92. https://doi.org/10.1016/j.apgeochem.2014. 07.009

30. Al-Naeem AA (2016) Monitoring of groundwater salinity for water resources management in irrigated areas of Al-Jouf region. Saudi Arabia Res J Environ Sci 9(6):256-269. https://doi. org/10.3923/rjes.2015.256.269

31. Han D, Song X, Currell MJ (2016) Identification of anthropogenic and natural inputs of $\mathrm{SO} 4$ into a karstic coastal groundwater system in northeast China, Evidence from major ions, $\delta^{13} C_{D I C}$ and $\delta^{34} \mathrm{~S}_{\mathrm{SO} 4}$. Hydrology and Earth System Sciences 20:1983-1999. https://doi.org/10.5194/hess-20-1983-2016

32. Ibrahim Hussein HA, Ricka A, Kuchovsky T, El Osta MM (2017) Groundwater hydrochemistry and origin in the south-eastern part of Wadi El Natrun. Egypt Arab J Geosci 10(7):170. https:// doi.org/10.1007/s12517-017-2960-x

33. Najib S, Fadili A, Mehdi K, Riss K, Makan A (2017) Contribution of hydrochemical and geoelectrical approaches to investigate salinization process and seawater intrusion in the coastal aquifers of Chaouia, Morocco. J Contam Hydrol 198:24-36. https:// doi.org/10.1016/j.jconhyd.2017.01.003

34. Naseem S, Bashir E, Ahmed P, Rafique T, Hamza S, Kaleem M (2018) Impact of seawater intrusion on the geochemistry of groundwater of Gwadar District, Balochistan and its appraisal for drinking water quality Arab. J Sci Eng 43(1):281-293. https:// doi.org/10.1007/s13369-017-2679-8

35. Shi X, Wang Y, Jiao JJ, Zhong J, Wen H, Dong R (2018) DongAssessing major factors affecting shallow groundwater geochemical evolution in a highly urbanized coastal area of Shenzhen City. China J Geochem Explor. 184(17):17-27. https://doi.org/ 10.1016/j.gexplo.2017.10.003

36. Michael HA, Russoniello CJ, Byron LA (2013) Global assessment of vulnerability to sea-level rise in topography-limited and recharge-limited coastal groundwater systems. Water Resour Res 49:2228-2240. https://doi.org/10.1002/wrcr.20213

37. Mthembu P, Elumalai V, Brindha K, Li P (2020) Hydrogeochemical processes and trace metal contamination in groundwater: Impact on human health in the maputaland coastal aquifer. South Africa Exposure and Health 12:403-426. https://doi.org/ 10.1007/s12403-020-00369-2

38. Chidambaram S, Ramanathan AL, Srinivasamoorthy K, Anandhan P (2003) WATCLAST-a computer program for hydrogeochemical studies. Recent trends in Hydrogeochemistry (case studies from surface and subsurface waters of selected countries). Capital Publishing Company, New Delhi, pp 203-207

39. Chidambaram S, Bhandary H, Hadi K (2020) CHIDAM -A software for chemical interpretation of the dissolved ions in aqueous media. Groundw Sustain Dev. https://doi.org/10.1016/j.gsd. 2020.100496

40. Vetrimurugan E, Dlamini PN, Natarajan R (2019) Evaluation of high fuoride contaminated fractured rock aquifer in South Africa- Geochemical and chemometric approaches. Chemosphere. https://doi.org/10.1016/j.chemosphere.2019.06.065

41. Vetrimurugan E, Elango L, Rajmohan N (2013) Sources of contaminants and groundwater quality in the coastal part of a river delta. Int J Environ Sci Technol 10:473-486 
42. Vetrimurugan E, Elango L (2014) Groundwater chemistry and quality in an intensively cultivated, river delta. Water Qual Expo Health 7:125-141. https://doi.org/10.1007/s12403-014-0133-7

43. Narayanan RM, Radhika K, Lakshmi Priya C, Laxmipriya S, Krishnakumari B (2019) Simulation and modeling of seawater intrusion around pondicherry coastal aquifer-India Proceedings of the SMART-2019, In: IEEE conference ID: 46866 8th international conference on system modeling \& advancement in research trends.

44. Sabarathinam C, Bhandary H, Al-Khalid A (2020) Tracing the evolution of acidic hypersaline coastal groundwater in Kuwait. Arab J Geosci 13:1146. https://doi.org/10.1007/s12517-020-06116-w

45. Bhandary H, Sabarathinam C, Al-Khalid A (2018) Occurrence of hypersaline groundwater along the coastal aquifers of Kuwait. Desalination 436:15-27. https://doi.org/10.1016/j.desal.2018.02. 004

46. Sridharan $M$, Senthil Nathan D (2017) Hydrochemical facies and ionic exchange in coastal aquifers of puducherry region. Implications for Seawater Intrusion Earth Syst Environ, India. https:// doi.org/10.1007/s41748-017-0006-x

47. Sundaram VLK, Dinesh G, Ravikumar G, Govindarajalu D (2008) Vulnerability assessment of seawater intrusion and effect of artificial recharge in Pondicherry coastal region using GIS. Indian Journal of Science and Technology http://www.indjst.org Vol.1 No 7 Indian J.Sci.Technol.

48. Pethaperumal S, Chidambaram S, Prasanna MV, Verma VN, Balaji K, Ramesh R, Karmegam U, Paramaguru P (2008) A study on groundwater quality in the Pondicherry region. ECO -Chronicle 3:2.

49. Thilagavathi R, Chidambaram S, Prasanna MV, Pethaperumal S (2013) A study on the interpretation of spontaneous potential and resistivity logs in layered aquifer sequence of Pondicherry Region, South India. Arab J Geosci 7:3715-3729

50. Thilagavathi R, Chidambaram S, Ramanatahan AL, Rao MS, Prasanna MV, Tirumalesh K, Pethaperumal S (2013) An attempt to evaluate the influence of geomorphology on the hydrogeology of coastal aquifer. Indian J Geomorphol 18(2):103-114

51. Chidambaram S, Prasanna MV, Karmegam U, Singaraja $C$, Pethaperumal S, Manivannan R, Anandhan P, Tirumalesh $\mathrm{K}$ (2011) Significance of pCO2 values in determining carbonate chemistry in groundwater of Pondicherry region. India. Front Earth Sci 5(2):197-206. https://doi.org/10.1007/ s11707-011-0170-5

52. Tirumalesh K (2012) Characterization of groundwater in the coastal aquifers of pondicherry region using chemical, isotopic and geochemical modelling approaches. Unpublished thesis.

53. Tirumalesh K, Ramakumar KL, Prasad MBK, Chidambaram S, Perumal P, Prakash D, Nawani N (2015) Microbial evaluation of groundwater and its implications on redox condition of a multilayer sedimentary aquifer system.Environ Processes.doi: https:// doi.org/10.1007/s40710-015-0067-5.

54. Pethaperumal S (2010) Study on groundwater chemistry in the Pondicherry region. Ph.D. thesis, Annamalai University, India.

55. Thilagavathi R, Chidambaram S, Thivya C, Prasanna MV, Pethaperuamal S, Tirumalesh K (2014b) A study on the behaviour of total carbon and dissolved organic carbon in Groundwaters of Pondicherry Region, India. Int J Earth Sci Eng, 1537-1550, ISSN 0974-5904, 07, 04.

56. Thilagavathi R, Chidambaram S, Pethaperuamal S, Thivya C, Rao MS, Tirumalesh K, Prasanna MV (2016) An attempt to understand the behaviour of dissolved organic carbon in coastal aquifers of Pondicherry region. South India Environm Earth Sci 75:235

57. Thilagavathi R, Chidambaram S, Thivya C, Prasanna MV, Tirumalesh K, Pethaperuamal S (2016) Dissolved organic carbon in multilayered aquifers of pondicherry region (India): spatial and temporal variability and relationships to major ion chemistry. Nat Resour Res. https://doi.org/10.1007/s11053-016-9306-3

58. Thilagavathi R, Chidambaram S, Thivya C, Prasanna MV, Tirumalesh K, Pethaperumal S (2017) Assessment of groundwater chemistry in layered coastal aquifers using multivariate statistical analysis. Sustain Water Resour Manag 3(1):55-69

59. Thilagavathi R, Chidambaram S, Panda BR, Tirumalesh K, Devaraj N, Kurmana A (2017) Understanding the Decadal Variation of the Groundwater Resources along the Coastal Aquifers of Pondicherry - A Climate Change Perspective. J Climate Change 3(2):25-42. https://doi.org/10.3233/JCC-170012

60. Thilagavathi R, Chidambaram S, Thivya C, Tirumalesh K, Venkatramanan S, Pethaperumal S, Prasanna MV, Ganesh N (2019) Influence of variations in rainfall pattern on the hydrogeochemistry of coastal groundwater-an outcome of periodic observation. Environ Sci Pollut Res. https://doi.org/10.1007/ s11356-019-05962-w

61. Central Groundwater Board (2017) Ground water level scenario in India report, pp 1-30.

62. Central Ground Water Board (CGWB) (2007) Groundwater brochure of Puducherry region U.T of Puducherry, pp 1-27. http:// www.cgwb.gov.in/District Profile/Puduchery/Puducherry .pdf

63. Thilagavathi R, Chidambaram S, Prasanna MV, Thivya C, Singaraja C (2012) A study on groundwater geochemistry and water quality in layered aquifers system of Pondicherry region, southeast India. Appl Water Sci. https://doi.org/10.1007/ s13201-012-0045-2

64. American Public Health Association (APHA) (1985) Standard methods for the examination of water and waste, 16th edn. Am. Public Health Assoc, Washington, DC, USA, p 100

65. WHO (2004) Guidelines for drinking water quality; 3rdedn, vol 1. Recommendations, Geneva, p 515

66. Mollema PN (2016) Water and chemical budgets of gravel pit lakes: case studies of fluvial gravel pit lakes along the Meuse river (The Netherlands) and Coastal Gravel Pit Lakes along the Adriatric Sea (Ravenna, Italy). Ph.D. Thesis, DOI: https://doi.org/ 10.4233/uuid:875dc7a9-c8bc-4255-95d7-23249ac38748.

67. Sarath Prasanth SV, Magesh NS, Jitheshlal KV, Chandrasekar N, Gangadhar K (2012) Evaluation of groundwater quality and its suitability for drinking and agricultural use in the coastal stretch of Alappuzha District, Kerala. India Appl Water Sci 2(3):165-175. https://doi.org/10.1007/s13201-012-0042-5

68. Faizal Khan AF, Srinivasamoorthy K, Rabina C (2020) Hydrochemical characteristics and quality assessment of groundwater along the coastal tracts of Tamil Nadu and Puducherry. India Appl Water Sci 10:74. https://doi.org/10.1007/ s13201-020-1158-7

69. Mercado A (1985) The use of hydrogeochemical patterns in carbonate sand and sandstone aquifers to identify intrusion and flushing of saline waters. Groundwater. https://doi.org/10. 1111/j.1745-6584.1985.tb01512.xISBN:1745-6584

70. El Moujabber M, BouSamra B, Darwish T, Atallah T (2006) Comparison of different indicators for groundwater contamination by seawater intrusion on the Lebanese coast. Water ResourManag 20:161-180. https://doi.org/10.1007/s11269-006-7376-4

71. Chidambaram S, Prasanna MV, Vasu K, ShahulHameed A, UnnikrishnaWarrier C, Srinivasamoorthy K (2007) Study on the stable isotope signatures in groundwater of Gadilam river basin Tamilnadu, India. Indian J Geochem 22(2):209-221

72. Chidambaram S, Ramanathan A, Prasanna MV (2010) Study on the hydrogeochemical characteristics in groundwater, post- and pre-tsunami scenario, from Portnova to Pumpuhar, southeast coast of India. Environ Monit Assess 169:553-568. https://doi. org/10.1007/s10661-009-1196-y

73. Prasanna MV, Chidambaram S, Pethaperumal S, Srinivasamoorthy K, John Peter A, Anandhan P, Vasanthavigar M (2008) 
Integrated geophysical and chemical study in the lower subbasin of Gadilam River, Tamilnadu, India. Environmental Geosciences 15(4):145-152. https://doi.org/10.1306/eg.1108070701

74. Prasanna MV, Chidambaram S, ShahulHameed A, Srinivasamoorthy K (2009) Study of evaluation of groundwater in Gadilam Basin using hydrogeochemical and isotope data.Environmental monitoring and assessment, doi: https://doi.org/10.1007/ s10661-009-1092-5.

75. Zaidi FK, Nazzal Y, Jafri MK, Naeem M, Ahmed I (2015) Reverse ion exchange as a major process controlling the groundwater chemistry in an arid environment: a case study from northwestern Saudi Arabia. Environ Monit Assess 187(10):607

76. Ravichandran K, Jayaprakash M (2011) Groundwater quality in Chennai Indian Society for Education and Environment. Indian J Sci Technol 4:6

77. Islam SMD, Bhuiyan MAH (2016) Impact scenarios of shrimp farming in coastal region of Bangladesh: an approach of an ecological model for sustainable management. Aquacultint. https://doi.org/10.1007/s10499-016-9978-z

78. Panpan Xu, Feng W, Qian H, Zhang Q (2019) Hydrogeochemical characterization and irrigation quality assessment of shallow groundwater in the central-western Guanzhong Basin, China. Int J Environ Res Public Health 16(9):1492. https://doi.org/10. 3390/ijerph16091492

79. Alam F (2014) Evaluation of hydrogeochemical parameters of groundwater for suitability of domestic and irrigational purposes: A case study from central Ganga Plain. India Arab J Geosci 7:4121-4131

80. Tahmasebi P, Mahmudy-Gharaie MH, Ghassemzadeh F, Karouyeh AK (2018) Assessment of groundwater suitability for irrigation in a gold mine surrounding area. NE Iran Environ Earth Sci 77:766

81. Khalid S (2019) An assessment of groundwater quality for irrigation and drinking purposes around brick kilns in three districts of Balochistan province, Pakistan, through water quality index and multivariate statistical approaches. J Geochem Explor 197:14-26

82. Chadha DK (1999) A proposed new diagram for geochemical classification of natural waters and interpretation of chemical data. Hydrogeol. https://doi.org/10.1007/s100400050216

83. Karmegam U, Chidambaram S, Sasidhar P, Manivannan R, Manikandan S, Anandhan P (2010) Geochemical characterization of groundwaters of shallow coastal aquifer in and around Kalpakkam, South India. Res J Environ Earth Sci 2(4):170-177

84. Vandenbohede A, Courtens C, William de Breuck L (2010) Freshsalt water distribution in the central Belgian coastal plain: an update. GeolBelg 11(3):163-172

85. Papazotos P, Vasileiou E, Perrak M (2019) The synergistic role of agricultural activities in groundwater quality in ultramafic environments: the case of the Psachna basin, central Euboea, greece environmental monitoring and assessment. 191(5) DOI: https:// doi.org/10.1007/s10661-019-7430-3
86. Vengosh A, Gill J, Davisson ML, Hudson GB (2002) A multiisotope $(\mathrm{B}, \mathrm{Sr}, \mathrm{O}, \mathrm{H}$, and $\mathrm{C})$ and age dating study of groundwater from Salinas Valley, California: hydrochemistry, dynamics, and contamination process. Water Resour Res 38(1):1-17. https:// doi.org/10.1029/2001WR000517

87. Metcafe, Eddy (2000) Integrated aquifer management plan: final report. Gaza Coastal Aquifer Management Program, USAID Contract No. 294-C-00-99-00038-00.

88. CGWB (1993) Ground water resources and development prospects in Pondicherry region, Union Territory of Pondicherry.

89. Kumar M, Ramanathan AL, Rao MS, Kumar B (2006) Identification and evaluation of hydrogeochemical process in the groundwater environment of Delhi. Environ Geol, India. https://doi.org/ 10.1007/s00254-006-0275-4

90. Ruiz F, Gomis V, Blasco P (1990) Application of factor analysis to the hydrogeochemical study of a coastal aquifer. J Hydrol 119:169-177. https://doi.org/10.1016/0022-1694(90)90041-U

91. Voudouris K, Lambrakis N, Papatheodorou G, Daskalaki P (1997) An application of factor analysis for the study of the hydrogeological conditions in Plio-Pleistocene aquifers of NW Achaia (NW Peloponnesus. Math Geol, Greece). https://doi.org/10.1007/ BF02769619

92. Chidambaram $S$, Ramanathan $A L$, Anandhan $P$, Srinivasamoorthy K, Prasanna MV (2005) A comparative study on the coastal surface and ground water in and around Puduchattiram to Coleroon, Tamil Nadu. Int J Ecol Environ Sci 31(3):209-306 (Special Issue)

93. Adithya VS, Keesari TK, Thivya C, Thilagavathi R, Venkatramanan S, Chidambaram S, Prasanna MV (2020) Seasonal changes in groundwater quality deterioration and chemometric analysis of pollution source identification in South India. Environ Sci Pollut Res. https://doi.org/10.1007/s11356-020-08258-6

94. Devaraj N., Chidambaram S., Panda B., Thivya C., Tirumalesh K., Thilagavathi R. (2020) Determination of anthropogenic sources in the groundwater chemistry along KT boundary of South India. In: Kumar M., Snow D., Honda R. (eds) Emerging issues in the water environment during anthropocene. Springer transactions in civil and environmental engineering. Springer, Singapore. doi: https://doi.org/10.1007/978-981-32-9771-5_7.

95. Chandrasekar T, Keesari T, Gopalakrishnan G et al (2021) Occurrence of heavy metals in groundwater along the lithological interface of K/T Boundary, Peninsular India: A special focus on source, geochemical mobility and health risk. Arch Environ Contam Toxicol 80:183-207. https://doi.org/10.1007/ s00244-020-00803-1

Publisher's Note Springer Nature remains neutral with regard to jurisdictional claims in published maps and institutional affiliations. 